\title{
Role of Cysteine Proteases and Protease Inhibitors in Gastric Mucosal Damage Induced by Ethanol or Ammonia in the Rat
}

\author{
Lajos Nagy, Stefano Kusstatscher, Peter V. Hauschka, ${ }^{\star}$ and Sandor Szabo \\ Chemical Pathology Research Division, Departments of Pathology, Brigham \& Women's Hospital, *Children's Hospital, \\ and Harvard Medical School, Boston, Massachusetts 02115
}

\begin{abstract}
Since recent studies suggest an imbalance between cathepsin B and its tissue protease inhibitors (PI) in the pathogenesis of acute and chronic diseases, we tested the hypothesis that release of activated cysteine proteases $(\mathrm{P})$ such as cathepsins $\mathrm{B}, \mathrm{H}$, and $\mathrm{L}$ might play a role in the pathogenesis of gastric hemorrhagic mucosal lesions (HML) induced by ethanol (E) or ammonia (A). Anesthetized rats received $1 \mathrm{ml}$ of $50 \% \mathrm{E}$ or $1 \%$ A solution intragastrically for 1 min during in situ gastric luminal perfusion. Rapid activation and release of cathepsins $\mathrm{B}, \mathrm{L}$, and $\mathrm{H}$ into the luminal perfusate preceded the formation of HML quantified by planimetry. Mucosal presence and activity of cysteine PI and cathepsin $B$ have also been investigated in the pathogenesis of chemically induced HML. We extracted and partially isolated acid and thermostable inhibitors of cathepsin B in the gastric mucosa, and found rapid inactivation of PI and activation of cathepsin B in the early phase of E- or A-induced HML. Negative correlations were found between P and PI activities by $\mathrm{E}$ or A solutions. Both the activation of cathepsins $\mathrm{B}, \mathrm{L}$, and $\mathrm{H}$ and the development of E-induced HML were prevented by pretreatment with the sulfhydryl alkylator $N$-ethylmaleimide. These results suggest that cysteine $\mathbf{P}$ may be activated in the rat stomach after $E$ or $A$ exposure, and cysteine $\mathrm{P}$ may have a role in the pathogenesis of $\mathrm{E}$ - or A-induced gastric HML. Endogenous PI may also participate in the mechanisms of gastric mucosal lesions and gastroprotection. (J. Clin. Invest. 1996. 98:1047-1054.) Key words: thiol proteases and inhibitors - gastric mucosal injury • Helicobacter pylori • gastroprotection
\end{abstract}

\section{Introduction}

Mammalian cysteine (thiol) proteases play important roles in intracellular and cytoskeletal protein turnover $(1,2)$, degradation of epidermal growth factor receptors (3), activation of other proteases such as the serine protease thrombin (4) and metalloprotease collagenase (5). These proteolytic enzymes have been implicated in the pathogenesis of emphysema (6), rheumatoid arthritis (7), glomerulonephritis (8), tumor growth and metastatic invasion $(9,10)$, and other diseases $(11)$.

Address correspondence to Sandor Szabo, Department of Pathology, University of California VA Medical Center (113), 5901 East 7th St., Long Beach, CA 90822. Phone: 310-494-5921; FAX: 310-494-5623.

Received for publication 28 February 1994 and accepted in revised form 21 June 1996.

J. Clin. Invest.

(C) The American Society for Clinical Investigation, Inc.

0021-9738/96/08/1047/08 \$2.00

Volume 98, Number 4, August 1996, 1047-1054
The exact role of pepsin, other aspartic proteases and various metallo- or serine-proteolytic enzymes remain unknown or controversial in the development of gastric mucosal injury and ulceration $(12,13)$. Our preliminary results demonstrated an activation and release of thiol protease cathepsin B after ethanol exposure in the rat stomach with continuous gastric perfusion (14). Both the increase in enzyme activity and development of hemorrhagic mucosal lesions (HML) ${ }^{1}$ were dose and time dependently prevented by sulfhydryl ( $\mathrm{SH}$ ) alkylators such as iodoacetate, iodoacetamide, $N$-ethylmaleimide (NEM) or its newly synthesized derivatives. Furthermore, positive correlations were found between the in vivo gastroprotection and in vitro blockade of protein $\mathrm{SH}$ groups, or between gastroprotection and inhibition of cysteine proteases $(15,16)$.

Ammonia $\left(\mathrm{NH}_{3}\right)$, a product of Helicobacter pylori (HP), is one of the recently recognized mediators of gastric mucosal injury. It is more damaging (on molar basis) to the rat gastric mucosa than ethanol or $\mathrm{HCl}$ solutions (17). Ammonia is synthesized by urease of HP in the superficial layer of human gastric mucosa and participates in the pathogenesis of gastritis and in the maintenance of duodenal ulceration (18).

Since the molecular pathogenesis of chemically induced HML is unknown, the main goals of this study were: $(a)$ to investigate the presence and activity of cathepsin B and its endogenous inhibitors in the rat gastric mucosa, and $(b)$ to determine the simultaneous changes in the activity of protease inhibitors and cathepsin B after administration of gastrotoxic ethanol or ammonia-water. We also tested the hypothesis that in addition to cathepsin B other thiol cathepsins (e.g., H and L) might be present in the rat stomach and play a role in the pathogenesis of mucosal damage induced by ethanol or ammonia.

\section{Methods}

Materials. Cathepsin B (EC 3.4.22.1) (from bovine spleen, $22 \mathrm{U} / \mathrm{mg}$ protein, $8.3 \mathrm{U} / \mathrm{mg}$ solid) $\alpha$ - $N$-benzyloxycarbonyl-L-arginyl-L-arginine-4methoxy- $\beta$-naphthylamide (Z-A/A-Arg-Arg-MNA), $\alpha-N$-benzoyl-DLarginine 2-naphthylamide (Arg-MNA), $\alpha-N$-benzyloxycarbonyl-phenylalanine-arginine-4-methoxy- $\beta$-naphthylamide (Z-Phe-Arg-MNA) substrates, and 4-methoxy-2 naphthylamide- $\mathrm{HCl}$ ( $\mathrm{HCl}-\mathrm{MNA}$ ) were purchased from Enzyme Systems Products (Livermore, CA). BSA, L-cysteine free base, polyoxyethylene 23 lauryl ether (Brij 35), NEM, EDTA disodium, DMSO, perchloric acid, sodium chloroacetate, sodium phosphate dibasic, potassium phosphate monobasic, and $10 \%$ neutral buffered formalin, were obtained from Sigma Chemical Co. (St. Louis, MO). Glacial acetic acid, sodium acetate and ammonium hydroxide were from Fisher Scientific Co. (Springfield, NJ). Pentobarbital sodium $\left(\mathrm{Nembutal}^{\mathrm{R}}\right.$ ) was from Abbot Laboratories (North Chicago, IL). Absolute ethanol from Florida Distillers (Lake Alfred,

1. Abbreviations used in this paper: HML, hemorrhagic mucosal lesions; IU, inhibitory units; MNA, 4-methoxy-2 naphthylamide; NEM, $\mathrm{N}$-ethylmaleimide; $\mathrm{SH}$, sulfhydryls. 
FL) was used. All other reagents and solvents were of the highest purity commercially available.

Gastric luminal perfusion, in situ. In fasted, anesthetized (0.45 $\mathrm{mg} / 100$ gram pentobarbital sodium, intraperitoneally) female SpragueDawley rats (160-210 gram) (Taconic Farms, Germantown, NY), middle laparotomy was performed, the forestomach opened, and the stomach carefully rinsed with saline. A soft plastic tube with three to six openings was inserted into the stomach and fixed. The duodenum was also opened $2 \mathrm{~cm}$ below the pylorus and another tube placed into the stomach and tightened with a silk-ligature around the proximal duodenum containing the cannula. The stomach was perfused in situ (Travenol peripump; Travenol Laboratories, Inc., Morton Grove, IL $60093)$ with warm $\left(37^{\circ} \mathrm{C}\right)$ saline using $1.5 \mathrm{ml} / \mathrm{min}$ flow rate. The gastric contents (enzyme samples for cathepsins $\mathrm{B}, \mathrm{B}+\mathrm{L}$, and $\mathrm{H}$ ) were collected in Eppendorf tubes at 1-min intervals 5 min before (period of stabilization) and $15 \mathrm{~min}$ after the $1 \mathrm{ml}$ of $1 \%$ (vol/vol) ammoniawater or $50 \%(\mathrm{vol} / \mathrm{vol})$ ethanol which were given by gavage for $1 \mathrm{~min}$ in the temporarily occluded and emptied stomach. Namely, the gastric content was carefully aspirated before and after the chemical exposures. In other groups of rats NEM ( 0.1 or $1.0 \mathrm{mg} / 100$ grams) was given intragastrically (i.g.) by gavage $30 \mathrm{~min}$ before $1.0 \mathrm{ml}$ of $50 \%$ ethanol. The release of cathepsins $\mathrm{B}, \mathrm{B}+\mathrm{L}$, and $\mathrm{H}$ into the gastric perfusate as well as the extent of HML were measured. At the end of perfusion the animals were killed by cervical dislocation, the stomachs fixed in $10 \%$ formalin, and the extent of HML was quantified by computerized stereomicroscopic planimetry. The area of HML was expressed as percentage of glandular mucosa.

Release of cathepsin B in conscious rats. To supplement the gastric perfusion experiments performed in anesthetized animals, groups of fasted rats were given, by rubber stomach tube, $1 \mathrm{ml}$ of either saline or $75 \%$ ethanol and killed 1, 3, or 6 min later. To facilitate the collection of released enzymes, $1 \mathrm{ml}$ of saline was injected into the stomach after the distal esophagus and pylorus were clamped. Subsequently, the stomach was removed, opened, and the gastric content collected for the measurement of cathepsin B activity. The stomach was fixed in $10 \%$ formalin and the area of HML was measured by computerized planimetry coupled with stereomicroscopy.

Preparation of gastric mucosal extracts for protease inhibitors and cathepsin B. Fasted rats were given $1 \mathrm{ml}$ of $75 \%$ (vol/vol) ethanol or $1 \%(\mathrm{vol} / \mathrm{vol})$ ammonia-water i.g., and killed by cervical dislocation 1 , $3,6,12$, or $15 \mathrm{~min}$ later. The stomachs were removed and opened along the greater curvature and divided into two equal parts for quantification of HML by planimetry and for preparation and measurements of mucosal cathepsin B and thiol protease inhibitors from glandular mucosa. The preparation of enzyme and inhibitor samples was carried out by modified methods as described previously $(19,20)$. The oxyntic gland area of stomach mucosa was carefully scraped with a blunt knife, weighed, and put in ice-cold phosphate buffer (1:10 wt/ vol) ( $0.1 \mathrm{M}, \mathrm{pH}$ 6.0). Tissue samples were homogenized twice for $30 \mathrm{~s}$ with an ultra turrax tissue disrupter (Tissumizer; Tekmar Co., Cincinnati, $\mathrm{OH})$ at $50,000 \mathrm{rpm}$ and placed in ice bath $\left(0-4^{\circ} \mathrm{C}\right)$ before centrifuging $(6,000 \mathrm{~g}, 15 \mathrm{~min})$ in cold biochemical procedure room. A 15-50 $\mu l$ aliquot of supernatant was used as enzyme sample in our standard cathepsin B assay.

Another aliquot (0.5-1.0 ml) of aqueous supernatant was treated with $6 \%(\mathrm{wt} / \mathrm{vol})$ of perchloric acid $(1: 1, \mathrm{vol} / \mathrm{vol})$ and the mixture carefully heated in $60^{\circ} \mathrm{C}$ shaking water bath for $3 \mathrm{~min}$ and centrifuged $(6,000 \mathrm{~g}, 15 \mathrm{~min})$. The clear supernatant was treated with $6.0 \mathrm{M}$ potassium carbonate solution (up to $\mathrm{pH} 6.0$ ), then cooled in refrigerator $\left(4^{\circ} \mathrm{C}\right)$ for minimum $30 \mathrm{~min}$ and centrifuged $(6,000 \mathrm{~g}, 15 \mathrm{~min})$ for removal of potassium perchlorate pellet. This supernatant solution contained all acid- and thermo-stable protease inhibitors including cathep$\sin \mathrm{B}$ antiproteases.

Assays of cathepsin $B, L$, and $H$. Cathepsins were activated by L-cysteine base $(2.0 \mathrm{mM})$ and EDTA $(1.0 \mathrm{mM})$ to hydrolyze 4-methoxy-2naphthylamide (MNA) from their specific synthetic substrate which is detectable by direct fluorimetry. The assays were carried out according to the method of Barrett with slight modifications (21).
Assay of cathepsin B. 10-50 $\mu$ l of mucosal enzyme sample (diluted in $0.1 \%$ (wt/vol) Brij 35) or $300 \mu l$ gastric content was incubated with $5 \mathrm{nmol}$ Z-A/A-Arg-Arg-MNA dissolved in DMSO $(10 \mathrm{mM})$, and diluted in $0.1 \%$ Brij 35 in $0.1 \mathrm{M}$ potassium-sodium phosphate buffer ( $\mathrm{pH} \mathrm{6.0)}$ at $37^{\circ} \mathrm{C}$ in a shaking water bath (Blue M Electric Co., Blue Island, IL) for $10 \mathrm{~min}$ in a total volume of $1.0 \mathrm{ml}$ in presence of 2 $\mu \mathrm{mol} L$-cysteine and $1 \mu \mathrm{mol} \mathrm{Na} 2$ EDTA. Parallel substrate control assay was performed with buffer containing $100 \mu \mathrm{mol}$ chloroacetate instead of L-cysteine. The reaction was terminated with $1.0 \mathrm{ml}$ of 50 $\mathrm{mM}$ Na chloroacetate dissolved in $0.1 \mathrm{M}$ acetate buffer ( $\mathrm{pH} 4.3)$. The intensity of free MNA-induced fluorescence was measured by fluorescence spectrophotometer (204-A Perkin-Elmer; Hitachi Instruments, Inc., Tokyo, Japan) (ex: 338 nm, em: 418 nm, P.M. gain: 3, sensitivity: 1) against distilled water. Specific activity in mucosal samples $(\mu \mathrm{U} / \mathrm{mg}$ protein) or relative enzyme activity $(\mu \mathrm{U} / \mathrm{ml})$ in the gastric content was calculated from freshly prepared MNA standard curve. 1 $\mathrm{mU}$ cathepsin $\mathrm{B}$ activity was defined as the amount of enzyme that hydrolyzed $1 \mathrm{nmol}$ substrate $/ \mathrm{min}$ at $37^{\circ} \mathrm{C}$ (releasing also $1 \mathrm{nmol}$ MNA).

Assay of cathepsin L. Cathepsin L was assayed with cathepsin B using Z- Phe-Arg-MNA $(21,22)$ substrate with the same method and under the same conditions as those used to measure the Z-A/A-ArgArg-MNA-hydrolyzing activity of cathepsin B. Since this substrate is hydrolyzed by both cathepsins B and L, this hydrolytic activity was expressed as activity of cathepsin B $+\mathrm{L}$.

Assay of cathepsin $\mathrm{H}$. Cathepsin $\mathrm{H}$ was assayed with Arg-MNA (23) as substrate in $0.1 \mathrm{M}$ potassium-sodium phosphate buffer $(\mathrm{pH}$ 6.6) by the same method and under the same conditions as those used to measure activity of cathepsin B.

The fluorescence of MNA liberated from each substrate was determined as described in the cathepsin B assay.

Measurement of inhibitory activity. Aliquot of inhibitor sample $(100 \mu \mathrm{l})$ was measured in the standard enzyme assay against $2 \mu \mathrm{g}$ cathepsin B which was dissolved in $0.1 \%$ Brij 35 and activated with L-cysteine in Barrett's buffer ( $\mathrm{pH}$ 6.0). After formation of cathepsin B-inhibitor complex during $5 \mathrm{~min}$ preincubation at room temperature, the remaining enzyme activity was investigated in the presence of $5 \mathrm{nmol} \mathrm{Z-A/A-Arg-Arg-MNA} \mathrm{as} \mathrm{substrate} \mathrm{of} \mathrm{cathepsin} \mathrm{B} \mathrm{(as} \mathrm{pre-}$ viously reported). The activity of inhibitor samples was expressed as inhibitory units (IU/mg protein). One IU $=$ inhibition of $1 \mu \mathrm{g}$ cathep$\sin \mathrm{B}$ activity in the assay procedure.

Protein determination. Protein concentration of mucosal extract samples was determined by Bradford's Coomassie blue method spectrophotometrically $(595 \mathrm{~nm})$ with a spectrophotometer (2400-2; Gilford Instrument Laboratories, Inc., Oberlin, $\mathrm{OH}$ ) with standards of BSA (24). The protein concentration of inhibitor samples was measured in the original aqueous tissue homogenates (before acid treatment).

Fluorescent histochemical localization of cathepsin B. To investigate the localization of cathepsin $\mathrm{B}$ in the gastric mucosa, rats were killed and the stomach was rapidly removed, opened along the greater curvature, and rinsed. Sections of the glandular stomach were frozen and subsequently cut in cryostat. The sections $(5 \mu \mathrm{m})$ were placed on glass microscope slides and incubated in various concentrations of the same fluorescent substrate used in the biochemical experiments. Additional sections were preincubated in iodoacetate to inhibit cathepsin B and obtain information about the specificity of fluorescence. The cover-slipped slides were then examined by fluorescence microscopy (Nikon Optiphot with mercury lamp and BV filter [ex: 400 nm, em: 480 nm; Nikon Inc., Melville, NY]).

Data analysis. Each biochemical experiment was performed at least three times, the results from four to six rats were pooled and means \pm SEM values were calculated. The results of HML were expressed as percentage of glandular mucosa. Student's $t$ or MannWhitney $U$ tests were used for statistical analysis (significance: $P<$ $0.05)$. Linear regression and correlation were also calculated between activities of inhibitors and cathepsin B prepared from the same tissue samples. 

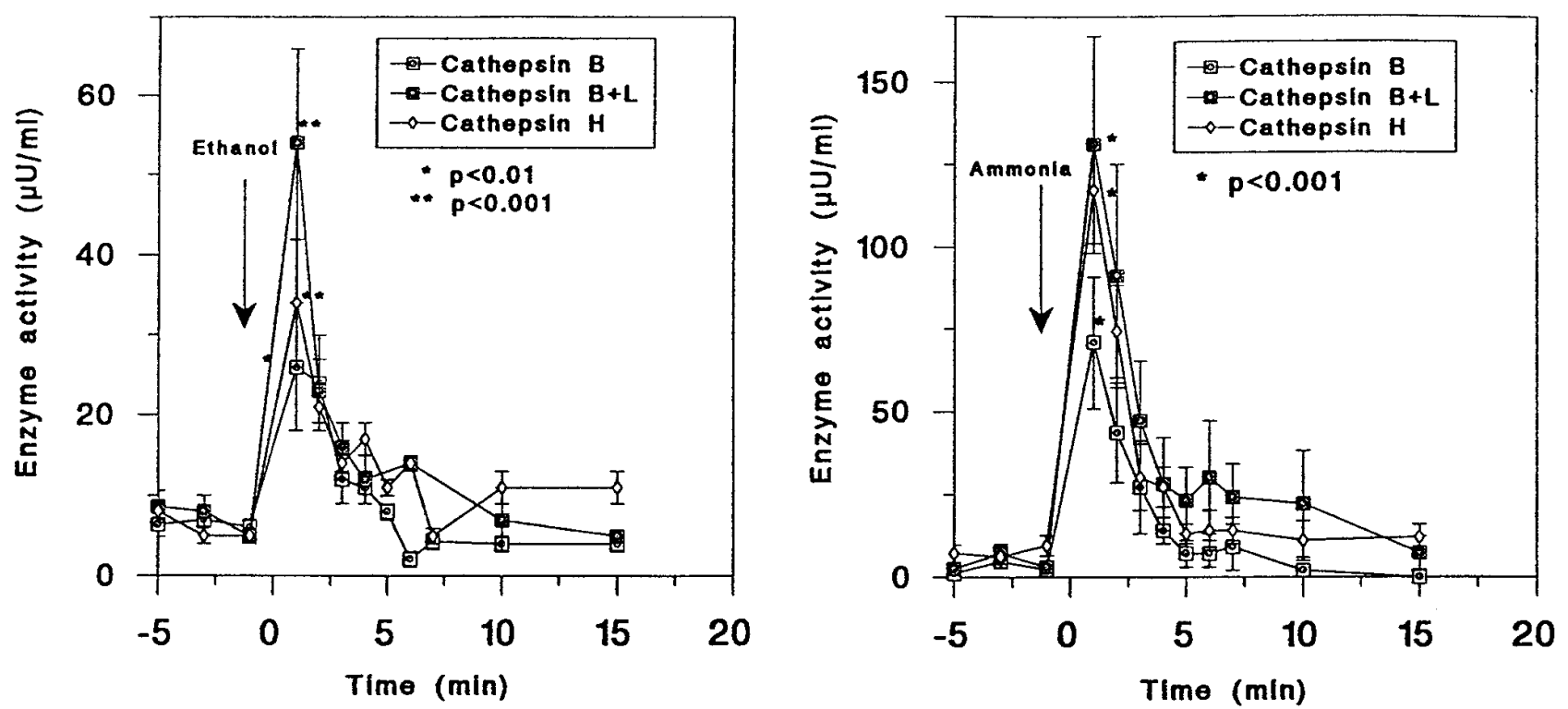

Figure 1. Release of cathepsins $\mathrm{B}, \mathrm{B}+\mathrm{L}$, and $\mathrm{H}$ into the gastric lumen after $1 \mathrm{ml} 50 \%$ ethanol (left) or $1 \%$ ammonia-water (right) i.g. administration in rats. All data presented are mean values of eight assays. 100-300 $\mu$ l of gastric content (enzyme sample) was diluted and activated in PBS containing $2 \mathrm{mM}$ cysteine and $1 \mathrm{mM} \mathrm{Na} \mathrm{F}_{2}$ EDTA at $\mathrm{pH} 6.0$ (cathepsin $B$ or $B+\mathrm{L}$ ) and $\mathrm{pH} 6.6$ (cathepsin $H$ ) and incubated with $5 \mathrm{mM}$ synthetic MNA substrates in $1-\mathrm{ml}$ volume at $37^{\circ} \mathrm{C}$ for $10 \mathrm{~min}$. Parallel samples were used as substrate controls diluted in inhibitor buffer solution, containing $100 \mu \mathrm{mol}$ chloroacetate instead of L-cysteine.

\section{Results}

Cysteine proteases and cysteine protease inhibitors in control rat stomach. The basal activity of cathepsin B in the glandular mucosa of control rat stomach was $100-155 \mu \mathrm{U} / \mathrm{mg}$ protein measured by specific synthetic fluorogen substrate. Marked protease inhibitor activity (0.8-1.2 IU/mg protein) against activated exogenous cathepsin B was also demonstrated in the heat- and acid-treated samples of mucosal homogenates of control rats.

In addition, $2-9 \mu \mathrm{U} / \mathrm{ml}$ relative activity of all three cysteine proteases (cathepsins $\mathrm{B}, \mathrm{B}+\mathrm{L}$, and $\mathrm{H}$ ) was found in the gastric content of anesthetized rats with gastric perfusion before the administration of chemicals (Fig. 1).

Activation and release of cathepsins $B, B+L$, and $H$ into gastric perfusate after ethanol or ammonia water administration. The activity $(\mu \mathrm{U} / \mathrm{ml})$ of cathepsin $\mathrm{B}, \mathrm{B}+\mathrm{L}$, and $\mathrm{H}$ in the gastric juice rapidly increased from $6.8 \pm 1.2,8.4 \pm 0.9,5.1 \pm 1.1$ to $26.1 \pm 8.0,54.1 \pm 12.0,33.4 \pm 8.1$ after $1 \mathrm{ml}$ of $50 \%$ ethanol exposure $(P<0.001)$, respectively (Fig. 1). Similarly, $1 \mathrm{ml}$ of $1 \%$ ammonia water also caused activation and leakage of cysteine proteases into the gastric lumen; the highest activities $(\mu \mathrm{U} / \mathrm{ml})$ of cathepsins B, B+L and, $\mathrm{H}$ were $43.5 \pm 7.5,131.0 \pm 18.0$, and $117.1 \pm 16.0(P<0.001)$, respectively. These proteolytic activities were two to four times higher in gastric contents after ammonia than after ethanol exposure (Fig. 1). The activity of all three cathepsins gradually decreased in the first 5 min to the level of basal values. In the activity of cathepsin B+L, most of the high values were due to cathepsin L.

By the end of gastric perfusion (15 min after the chemicals), severe HML were detected in the glandular stomach of all rats. Subsequent time-course studies revealed a gradual development of mucosal lesions which were practically absent in rats killed 1 min after the gastrotoxic chemicals, but by 6 min the extent of HML produced by ethanol or ammonia reached $6.8 \%(P<0.01)$ or $4.3 \%(P<0.05)$ of total glandular mucosa, respectively (Fig. 2$)$.

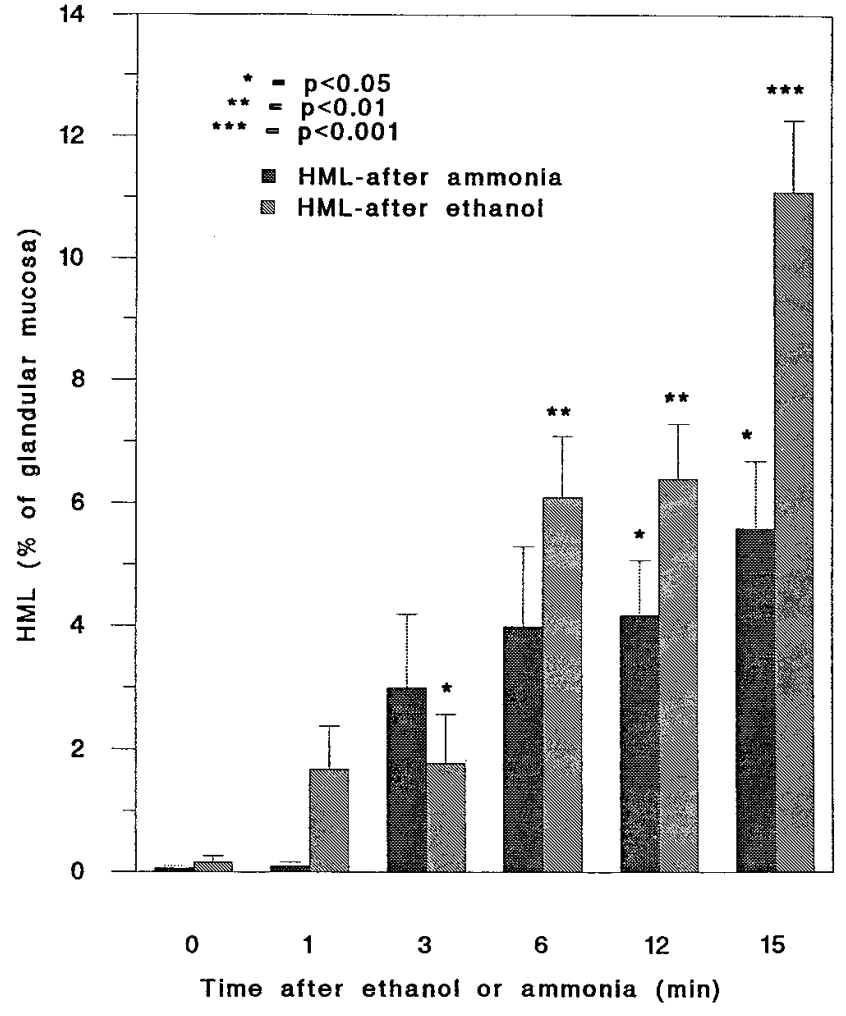

Figure 2. HML in the rat stomach after ethanol or ammonia-water administration. Data are expressed as mean $\pm \operatorname{SEM}(n=6$ in each group). Fasted rats were given $1 \mathrm{ml} 75 \%$ ethanol or $1 \%$ ammonia-water i.g. Area of HML (percentage of glandular stomach) was quantified by stereomicroscopic planimetry using half of the stomach. Cathepsin B-containing enzyme sample was extracted from aqueous homogenate of glandular mucosa (pH 6.0, PBS). Endogenous cathepsin B inhibitor(s) were prepared from mucosal homogenate by acid ( $6 \%$ perchloric acid) and heat treatment $\left(60^{\circ} \mathrm{C}, 3 \mathrm{~min}\right)$ from the other half of the glandular stomach. Statistical analysis: Mann-Whitney $U$ test, ${ }^{*}=P<0.05 ; * *=P<0.01$. 
Release of cathepsin B into gastric lumen of conscious rats. Results presented in Table I indicate a time-dependent release of cathepsin B into the gastric lumen of groups of nonanesthetized rats killed at 1,3 , or 6 min after i.g. administration of $1 \mathrm{ml}$ of $75 \%$ ethanol. This release of enzyme was accompanied by a gradual progression of HML (Table I).

Presence and modification of endogenous thiol protease inhibitors and cathepsin $B$ in the stomach after gastrotoxic chemicals. In vivo experiments revealed that during the early development of alcohol-induced HML, the activity of cysteine protease inhibitors (IU/mg protein) rapidly decreased from $1.17 \pm 0.19$ and reached the lowest value of $0.58 \pm 0.17(P<$ 0.01 ) at $6 \mathrm{~min}$ after $1 \mathrm{ml}$ of $75 \%$ ethanol (Fig. 3). The activity of endogenous cysteine protease inhibitors after $1 \%$ ammonia water administration was also markedly decreased from $0.82 \pm 0.08$ to $0.53 \pm 0.06(P<0.01)$ (Fig. 3). The inactivation of cysteine protease inhibitors in the rat gastric mucosa after either of the gastrotoxic chemicals reached statistical significance at $3 \mathrm{~min}$

In contrast, the specific activity $(\mu \mathrm{U} / \mathrm{mg}$ protein) of cathep$\sin \mathrm{B}$ in the glandular mucosa increased after $75 \%$ ethanol or $1 \%$ ammonia-water exposure from $155.1 \pm 19.0$ or $102.8 \pm 12$ to $225.0 \pm 26.0$ or $197.1 \pm 23$, respectively $(P<0.05)$. The highest cathepsin B activities were detected 3 min after chemicals, and then the values gradually decreased to levels lower than those in control rats (Fig. 4).

Correlations of these results revealed that the decrease in endogenous protease inhibitors was proportional to the enhanced activity of cathepsin B in the gastric mucosa after exposure to ethanol $(r=-0.691 ; P<0.029)$ or ammonia-water $(r=-0.58 ; P<0.01)$ (Fig. 5).
Table I. The Effect of Ethanol on the Release of Cathepsin B Into the Gastric Lumen in Conscious Rats

\begin{tabular}{lllc}
\hline Groups & \multicolumn{1}{c}{ Autopsy } & Cathepsin B & Mucosal lesions \\
\hline & time after ethanol & $m U / m l$ & $\%$ of glandular stomach \\
1. & 0 (controls) & $1.4 \pm 0.3$ & 0 \\
2. & $1 \mathrm{~min}$ & $2.7 \pm 0.6^{*}$ & $1.9 \pm 0.8$ \\
3. & $3 \mathrm{~min}$ & $3.2 \pm 0.7^{*}$ & $3.8 \pm 0.9$ \\
4. & $6 \mathrm{~min}$ & $3.9 \pm 0.8^{*}$ & $5.2 \pm 0.9$ \\
\hline
\end{tabular}

$* P<0.05$. Groups of rats $(n=6)$ were given by gavage $1 \mathrm{ml}$ saline (controls) or $75 \%$ ethanol and killed 1,3, or 6 min later. The distal esophagus and pylorus were clamped, the stomach rapidly removed and gastric juice was collected for measurement of cathepsin B activity. The area of hemorrhagic mucosal lesions was measured by stereomicroscopic computerized planimetry.

Effect of NEM on ethanol-induced release of cathepsins B, $B+L$, and $H$ in gastric perfusate and $H M L$. The time-dependent release of cathepsins $\mathrm{B}, \mathrm{B}+\mathrm{L}$, and $\mathrm{H}$ into the gastric perfusate after the administration of $1 \mathrm{ml}$ of $50 \%$ ethanol was decreased in rats pretreated with 0.1 or $1 \mathrm{mg} / 100$ gram of $\mathrm{SH}$ alkylator NEM i.g. (Fig. 6). In these animals, the area of HML was also dose dependently decreased (Fig. 7). Additional dose response studies with newly synthesized and less toxic NEM derivatives, (i.e., $N$-methyl, $N$-acetoxymethyl, $N$-chloromethyl, and $N$-benzyl maleimides) revealed potent gastroprotection against ethanol. This protection correlated with the inhibition of SH protease papain (15).
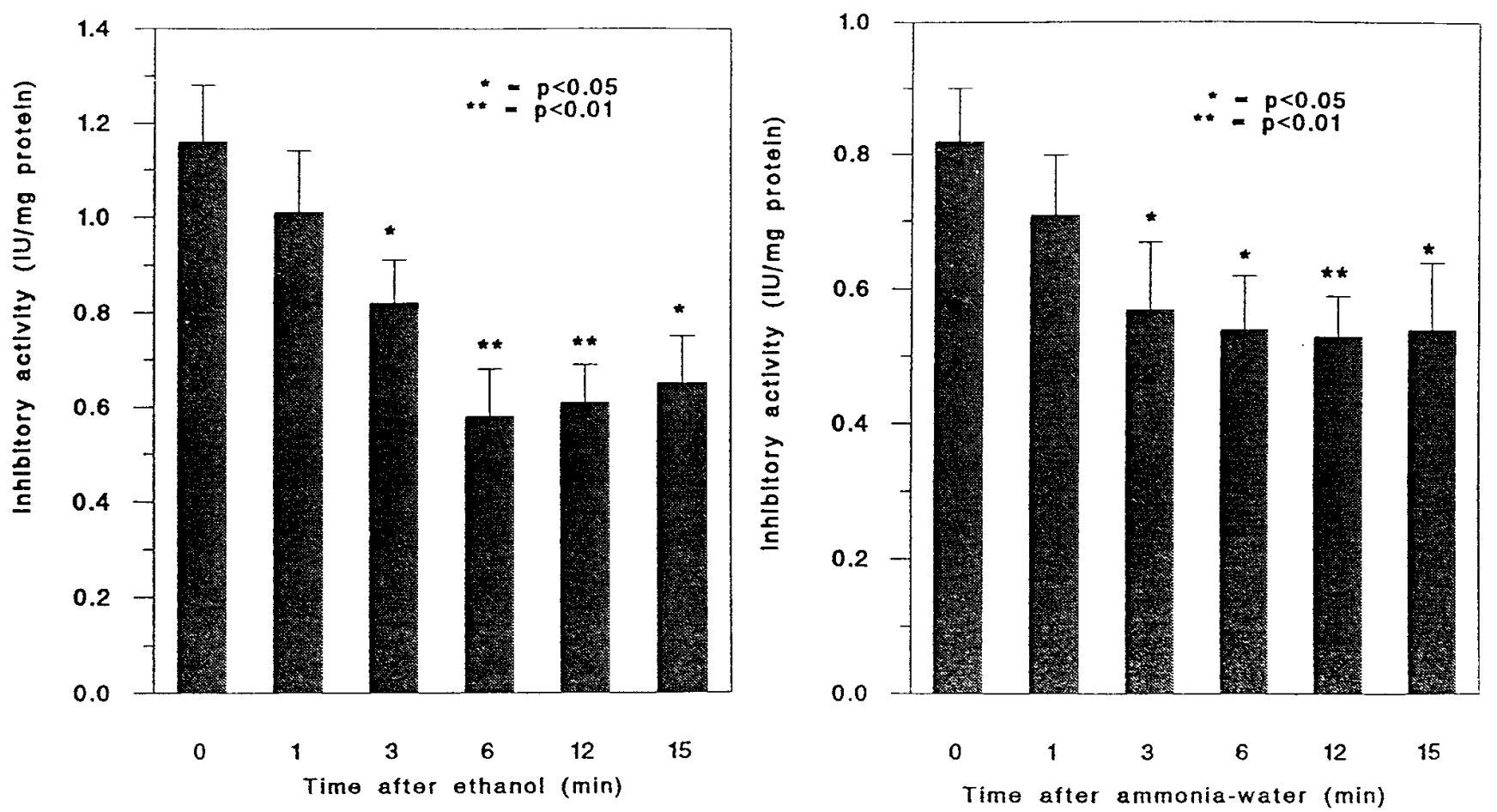

Figure 3. Endogenous cysteine protease inhibitory activities in the rat gastric mucosa after $1 \mathrm{ml} 75 \%$ ethanol (left) or $1 \%$ ammonia-water (right) i.g. administration. $100 \mu \mathrm{l}$ of inhibitor sample was carefully mixed and incubated with $2 \mu \mathrm{g}$ cathepsin B at room temperature for 5 min. The remaining catalytic activity of this mixture was investigated in our standard cathepsin B assay, as described in the text. 

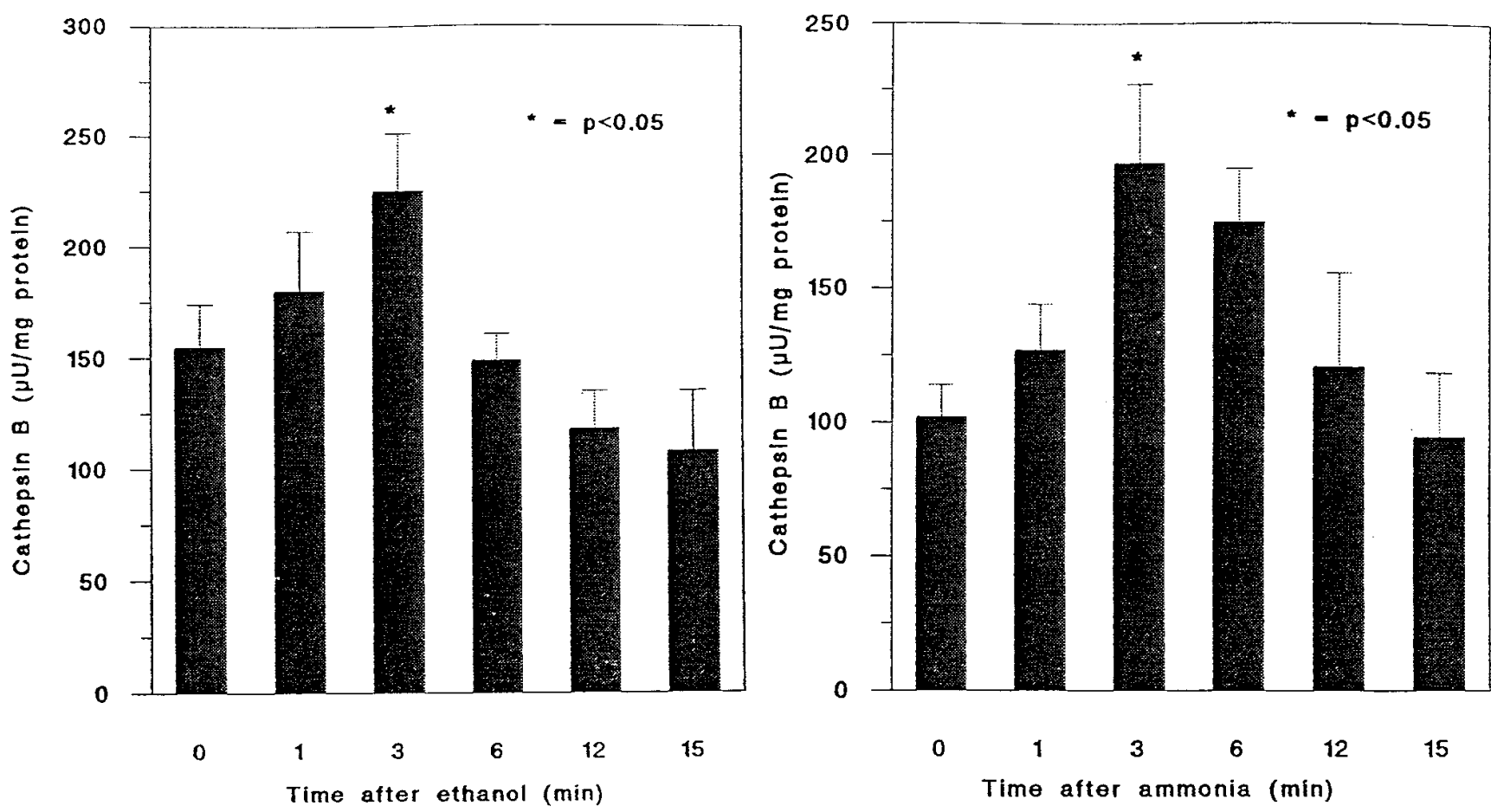

Figure 4. Cathepsin B activities in the rat gastric mucosa after $1 \mathrm{ml} 75 \%$ ethanol (left) or $1 \%$ ammonia-water (right) administration.

Histochemical localization of cathepsin B. Our fluorescent histochemical studies with cross sections of the glandular stomach revealed an uneven distribution of cathepsin B in the gastric wall. Sections incubated in low concentration of the fluorescent substrate revealed enzyme activity in the epithelial cells in the upper fourth of the mucosa (Fig. 8). Sections exposed to the same amount of substrate but for longer time, or short incubation in higher concentrations of the substrate demonstrated fluorescence in the lower part of the mucosa and muscle wall as well (Fig. 8). In contrast, frozen sections preincubated in iodoacetate revealed no fluorescence at all (Fig. 8).

\section{Discussion}

The present findings indicate that at least three types of thiol proteases, namely cathepsin $\mathrm{B}, \mathrm{L}$, and $\mathrm{H}$ as well as heat- and acid-stable cysteine protease inhibitors exist in the rat stom-
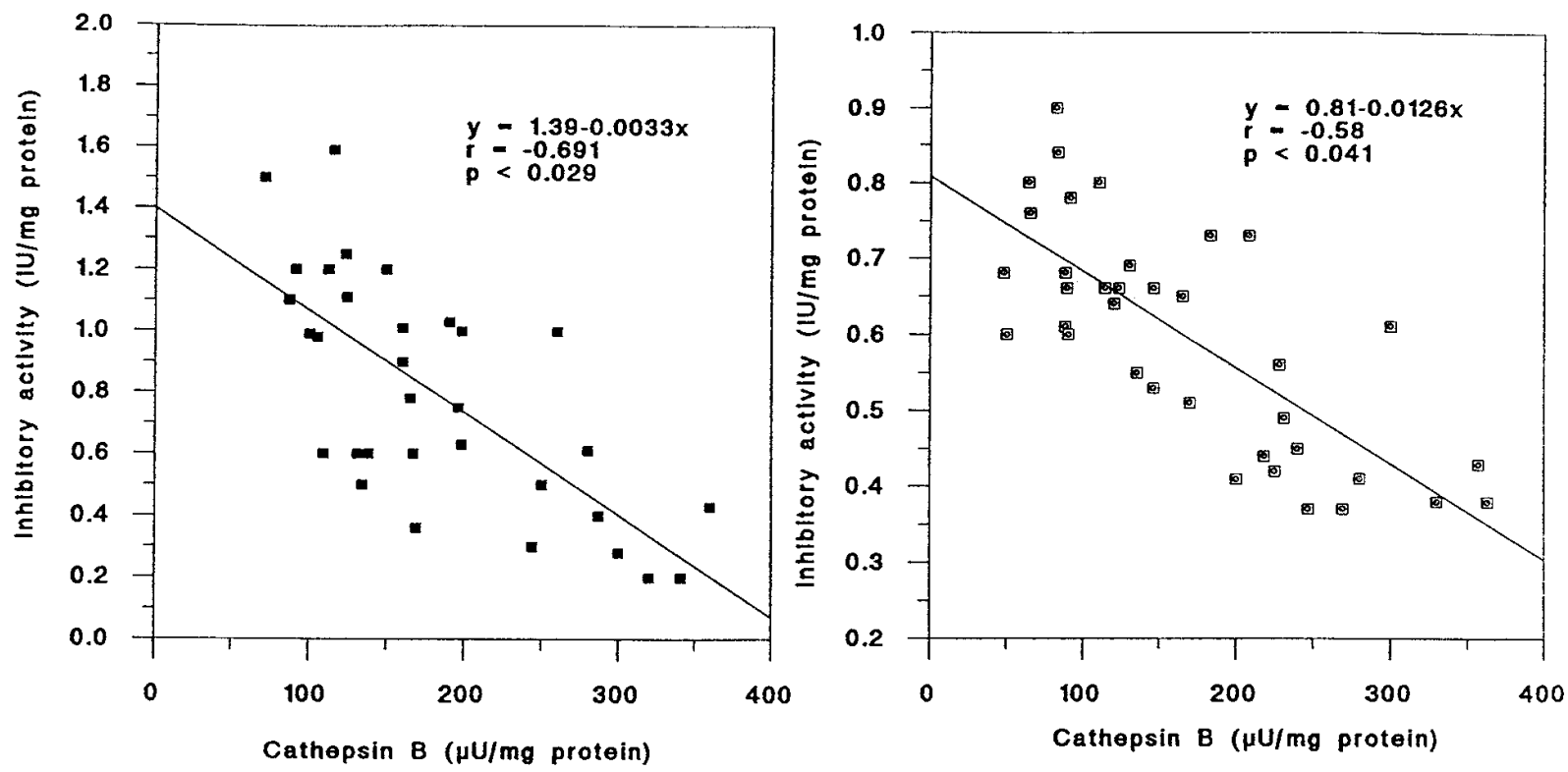

Figure 5. Correlations between cathepsin B and cysteine protease inhibitory activities in the rat gastric mucosa after $75 \%$ ethanol $(A)$ or $1 \%$ ammonia-water $(B)$ administration. 

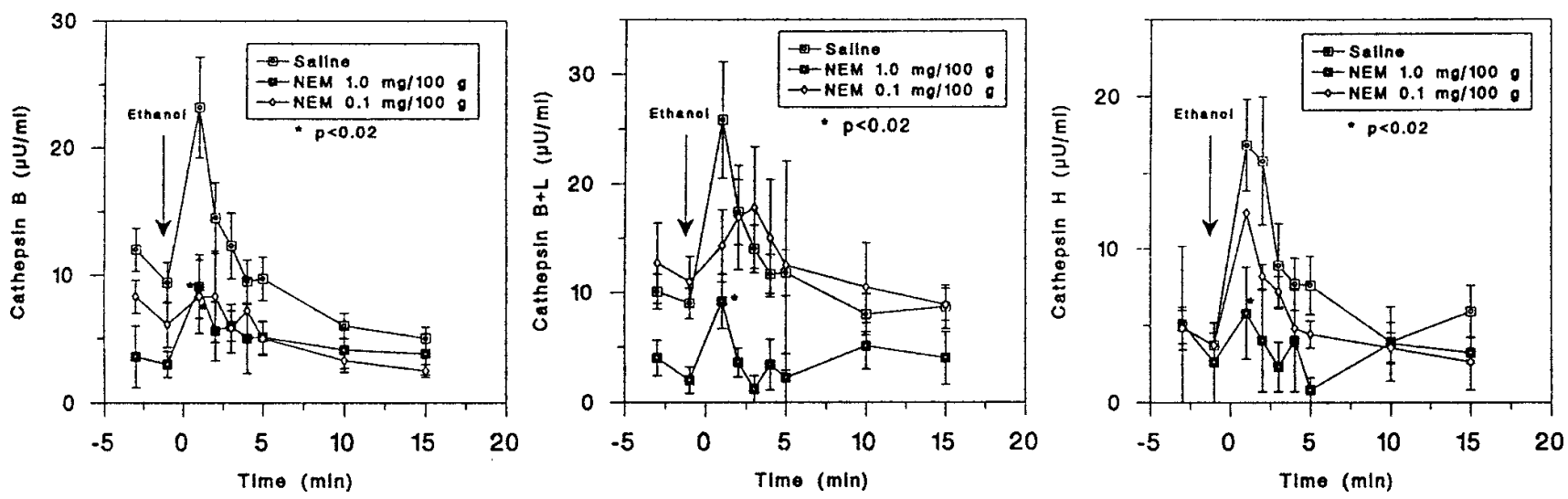

Figure 6. Effects of $N$-ethylmaleimide pretreatment on the release of cathepsin B (left), cathepsin $\mathrm{B}+\mathrm{L}$ (center), and cathepsin $\mathrm{H}($ right $)$ after 1 $\mathrm{ml}$ of $50 \%$ ethanol administration in rats.

ach. The activity of protease inhibitors rapidly decreased and the activity of cathepsin $\mathrm{B}$ increased in the rat glandular mucosa following i.g. administration of ethanol or ammonia-water solution. Similarly, these chemicals induced a rapid activation and release of cathepsin $\mathrm{B}, \mathrm{H}$, and $\mathrm{L}$ into gastric content in rats with in situ intragastric perfusion of anesthetized rats. Intragastric administration of ethanol also induced a rapid and time-dependent release of cathepsin B in conscious rats. The release of enzymes was decreased after pretreatment of rats with the SH alkylator NEM which also prevented the development of ethanol-induced HML. These studies thus demonstrate not only the successful detection of cysteine proteases and endogenous protease inhibitors in the stomach, but also indicate their modifications after exposure to gastrotoxic chemicals.

The basal proteolytic activities of these cathepsins were in the range of $2-10 \mu \mathrm{U} / \mathrm{ml}$ released mainly from the gastric surface epithelial cells. Our histochemical studies revealed a preferential localization of cathepsin B in the upper part of the mucosal epithelium which is usually first exposed to damaging agents. Rapid and substantial increase in the activity of cathepsins was detected in rats with gastric perfusion after i.g. administration of gastrotoxic chemicals such as ethanol (four to sevenfold) or ammonia-water solution (10-12-fold), as shown in Fig. 1. This activation of proteolytic enzymes might participate in the early formation of chemically induced mucosal lesions in the rat stomach, especially since pharmacologic inhibition of

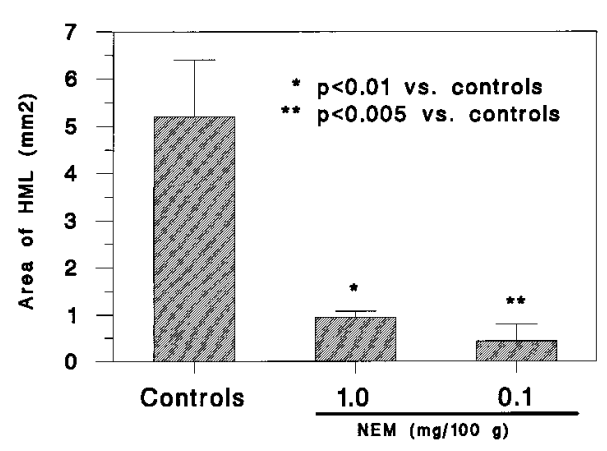

Figure 7. Effect of $\mathrm{N}$-ethylmaleimide pretreatment on HML induced by $50 \%$ ethanol. these enzymes was accompanied by prevention of chemically induced HML (14-16). We thus postulate that the gastric surface epithelium first exposed to damaging chemicals may release cysteine proteases which propagate the tissue injury by damaging the intracellular matrix, cells, and activating procollagenase, similar to the role of these enzymes in metastatic tumor spread (9). A critical stage in the development of HML is the involvement of vascular injury, i.e., when the propagation of damage reaches the subepithelial capillaries, endothelial damage, vascular stasis, and extravasation of red blood cells usually results in hemorrhagic necrosis (25-27).

One of the newly recognized mediators of gastric mucosal damage is ammonia which impairs mitochondrial and cellular respiration and energy metabolism, and decreases gastric mucosal cell viability leading to mucosal damage (18). H. pylorirelated gastric mucosal injury is associated with production of ammonia, which is a product of urea hydrolysis catalyzed by urease. In this study the ammonia-water solution induced not only extensive HML in the rat stomach, but also rapid release and activation of cathepsins B, L, and $\mathrm{H}$. These results strongly suggest that lysosomal and cytosolic cysteine cathepsins may play a role in the development of ethanol- and ammonia-induced gastric mucosal injury. The concentration of ammonia used in our experiments is similar or slightly higher than in patients whose stomach is infected with $H$. pylori $(28,29)$. Namely, our additional studies revealed that even lower concentrations of $\mathrm{NH}_{3}$ (e.g., $0.1 \%$ ) caused mucosal injury but to obtain rapidly developing HML comparable to those produced by ethanol, we had to use $1 \%$ ammonia-water.

We also investigated the presence and modification of both endogenous cysteine protease inhibitors and cathepsin B in rat glandular mucosa with or without ethanol or ammonia-water exposures. We found that both chemicals induced HML in the rat glandular mucosa within minutes after i.g. administration. The results with cathepsin B and its endogenous protease inhibitors revealed that after chemical exposure the activity of cysteine protease inhibitors decreased, and the specific activity of cathepsin B rapidly and significantly increased in the rat gastric mucosa. The enhancement of cathepsin B activity reached its highest level at $3 \mathrm{~min}$ after chemical exposures.

The negative correlations between the protease inhibitory activity and cathepsin B activity in the gastric mucosa after i.g. administration of chemicals revealed that an imbalance be- 

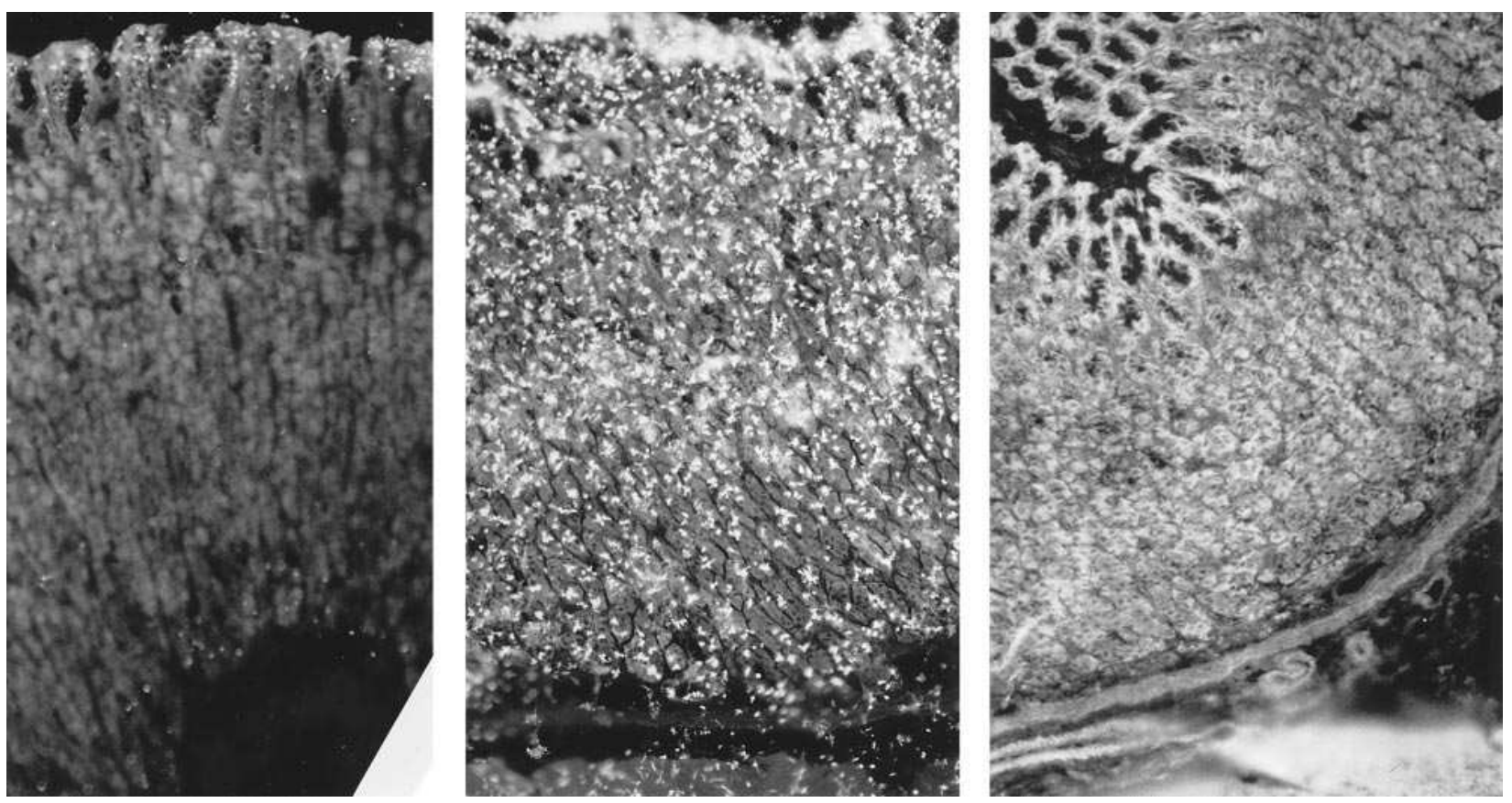

Figure 8. Fluorescent light microscopic histochemistry of sections of rat glandular stomach incubated in fluorescent substrate of cathepsin B without pretreatment (left and center) or after pretreatment with the inhibitor iodoacetate (right). (Left) Low substrate concentration and short incubation demonstrate enzyme activity (white spots indicating fluorescence) at the tip of the mucosa. (Center) More substrate or longer incubation show enzyme activity in all layers of rat stomach. (Right) No fluorescence is seen after preincubation with the enzyme inhibitor iodoacetate.

tween activation and inhibition of cathepsin $\mathrm{B}$ might be involved in the formation of acute HML in the rat stomach. The primary effect might be the inactivation of endogenous protease inhibitors which may contribute to the rapid activation of thiol protease cathepsin $\mathrm{B}$, and subsequent cell and tissue injury in the stomach. These enzymes released by parenchymal cells may rapidly degrade structural or enzymic proteins. Most proteases are associated with endogenous inhibitors and their inactivation (e.g., by free radicals, chemicals) results in activation of proteases $(2,19,20)$.

Mammalian cysteine proteases released from lysosomes or activated in cytosol (e.g., calpain) exert prominent cell, tissue, or organ destructive properties, and are important in the pathogenesis of acute or chronic diseases and pathologic events $(1-11,18)$. Until recently, four immunochemically distinguishable aspartic (acidic) proteases such as pepsinogen I, II, and cathepsins D and $\mathrm{E}$ have been found in the mammalian gastric mucosa (13). Unlike the controversial results concerning pepsin in the development of gastroduodenal ulceration, dose- and time-dependent gastroprotection was detected with cysteine protease inhibitors (i.e., SH-alkylators iodoacetate, NEM, new maleimide, or butyrophenone derivatives) against ethanol-induced HML in the rat stomach (15). In pursuing the biochemical-pharmacological characterization of cysteine proteases and endogenous protease inhibitors in the rat stomach, we found that in the stomach up to 56 or $24 \%$ of proteases was $\mathrm{SH}$-sensitive at $\mathrm{pH} 5.6$ or 7.4 , respectively (15). We conclude that one of the possible directly or indirectly acting endogenous mediators of gastric mucosal injury is the cysteine protease-endogenous protease inhibitor system, in addition to endothelins, eicosanoids, monoamines, platelet-activating factors, ammonia, bile acids, and $\mathrm{HCl}$ (30). Cysteine proteases, whose activities were extremely high in the early period of ammonia- or ethanol-induced mucosal lesions might be related to cellular or extracellular protein catabolism, cell and tissue damage, and gastroprotection.

\section{Acknowledgments}

The authors thank Romeo E. Morales, Eric Scarbrough, and Johanna Bishop for their excellent technical assistance, and Eileen Holman who helped in the preparation of the manuscript. We appreciate the expertise of Dr. Aron Vincze in helping us with the preparation of illustrations.

This study was supported in part by a grant from Marion Laboratories.

\section{References}

1. Polgár, L. 1988. The different mechanisms of protease action have a basic feature in common proteon transfer from the attacking nucleophil to the substrate leaving group. Acta Biochim. Biophys. Hung. 23:207-213.

2. Kirschke, H., and A.J. Barrett. 1987. In Lysosomes: Their Role in Protein Breakdown. H. Glaumann and F. J. Ballard, editors. Academic Press, London. 193-238.

3. Hiwasa, T., S. Sakiyama, S. Yokoyama, J.M. Ha, S. Noguchi, Y. Banda, E. Kominami, and N. Katunuma. 1988. Degradation of epidermal growth factor receptors by cathepsin L-like protease: inhibition of the degradation by c-Ha-Ras gene products. FEBS Lett. 233:367-370.

4. Ishii, H., M. Kobuki, J. Fujii, S. Hiraishi, and M. Kazama. 1990. Thiolprotease inhibitor EST can inhibit thrombin-induced platelet activation. Thrombosis Res. 57:847-861.

5. Khar, A. 1986. Activation of collagenase production in a rat macrophagelike cell line. Biochem. Int. 13:565-570.

6. Janoff, A., and H. Carp. 1982. Proteases, antiproteases, and oxidants: pathways of tissue injury during inflammation. Monogr. Pathol. 23:62-82.

7. Baici, A., and A. Lang. 1990. Cathepsin B secretion by rabbit articular chondrocyte: modulation by cycloheximide and glycosaminoglycans. Cell Tissue Res. 259:567-573.

8. Baricos, W.H., and S.V. Shah. 1991. Proteolytic enzymes as mediators of glomerular injury. Kidney Int. 40:161-173. 
9. Chung, S., and K. Kawai. 1990. Protease activities in gastric cancer tissues. Clin. Chim. Acta. 189:205-210.

10. László, A., I. Sohár, S. Karácsonyi, A. Petri, and I. Troján. 1990. Activities of serum cathepsins (B, H, and L) and metalloproteinase (MMP7-ase) in patients with gastrointestinal and bronchial malignant tumours. Acta Med. Hung. 47:107-109.

11. Buttle, D.J., M. Abrahamson, D. Burnett, J.S. Mort, A.J. Barrett, P.M. Dando, and S.L. Hill. 1991. Human sputum cathepsin B degrades proteoglycan is inhibited by $\mathrm{a}_{2}$-macroglobulin and is modulated by neutrophil elastase cleavage of cathepsin B precursor and cystatin C. Biochem. J. 276:325-331.

12. Ohe, K., N. Uneo, H. Yokoya, and A. Miyoshi. 1979. The activation of pepsinogen inside the gastric mucosa by the hydrogen ion back-diffusion during the course of aspirin ulceration. Hiroshima J. Med. Sci. 28:1-11.

13. Samloff, I.M. 1989. Peptic ulcer: the many proteinases of aggression. Gastroenterology. 96:586-595.

14. Szabo, S., G. Pihan, A. Raza, E.A. Mullen, and P.V. Hauschka. 1987. Multiple mechanisms of cell injury in the gastric mucosa. Fed. Proc. 48:1152.

15. Nagy, L., B. Saha, J.L. Neumeyer, S. Kusstatscher, and S. Szabo. 1993. Correlation between inhibition of cysteine proteases and gastroprotection by maleimide, acetophenone and butyrolactone derivatives: the predictive value of in vitro tests. Gastroenterology. 104:154a. (Abstr.).

16. Szabo, S., L. Nagy, and M. Plebani. 1992. Glutathione, protein sulfhydryls and cysteine proteases in gastric mucosal injury and protection. Clin. Chim. Acta. 206:95-105.

17. Szabo, S., L. Nagy, R.E. Morales, and Zs. Sandor. 1992. Ammonia is more damaging to the gastric mucosa than ethanol: role of sulfhydryls and vascular injury. Gastroenterology. 102:703a. (Abstr.).

18. Marshall, B.J., R.W. McCallum, and R.L. Guerrant. 1991. Helicobacter pylori in peptic ulceration and gastritis. Blackwell Scientific Publications, Boston, Oxford, London, Edinburgh, Melbourne, Paris, Berlin, Vienna. 226 pp.

19. Bradley, M.D., M. Kucera, M. Loeb, and B. Bernetová. 1989. Alterations in proteases, protease inhibitors and ecdysone levels: a profile of stress in insect. Comp. Biochem. Physiol. 94:85-89.

20. Fritz, H., I. Trautschold, and E. Werle. 1974. Protease inhibitors. In Methods of Enzymic Analysis. H.U. Bergmeyer, editor. Academic Press, New York. 1064-1089.

21. Barrett, A.J. 1980. Fluorimetric assays for cathepsin B and cathepsin H with methylcoumarylamide substrates. Biochem. J. 187:909-912.

22. Yamashita, M., and S. Konagaya. 1990. High activities of cathepsins B, $\mathrm{D}, \mathrm{H}$ and $\mathrm{L}$ in the white muscle of chum salmon in spawning migration. Comp Biochem. Physiol. 95B:149-152.

23. Schwartz, W.N., and A.J. Barrett. 1980. Human cathepsin H. Biochem. J. 191:487-497.

24. Bradford, M.M. 1976. A rapid and sensitive method for quantitation of microgram quantities of protein utilizing the principle of protein-dye binding. Anal. Biochem. 72:248-254.

25. Szabo, S., J.S. Trier, and A. Brown. 1985. Early vascular injury and increased permeability in gastric mucosal injury caused by ethanol in rat. Gastroenterology. 88:228-236.

26. Tarnawski, A., D. Hollander, J. Stachura, W.J. Krause, and H. Gergely. 1985. Prostaglandin protection of the gastric mucosa against alcohol injury-a dynamic time-related process. Gastroenterology. 88:334-352.

27. Trier, J.S., S. Szabo, and C.H. Allan. 1987. Ethanol-induced damage to mucosal capillaries of rat stomach. Ultrastructural features and effects of prostaglandin $\mathrm{F}_{2 \beta}$ and cysteamine. Gastroenterology. 92:13-22.

28. Gubbins, G.P., T.E. Moritz, L.S. Marsano, R. Talwalkar, C.J. McClain, and C.L. Mendenhall. 1993. Helicobacter pylori is a risk factor for hepatic encephalopathy in acute alcoholic hepatitis: the ammonia hypothesis revisited. Am. J. Gastroenterol. 88:1906-1910.

29. Neithercut, W.D., A.M. Nujumi, and R.E. McColl. 1993. Measurement of urea and ammonia concentrations in gastric juice. J. Clin. Pathol. 46:562-564.

30. Szabo, S. 1991. Mechanisms of gastric mucosal injury and protection. $J$. Clin. Gastroenterol. 13:S21-S34. 